\title{
THE CJEU AS AN INNOVATOR - A NEW PERSPECTIVE ON THE DEVELOPMENT OF INTERNET RELATED CASE-LAW
}

\author{
by
}

\section{ULF MAUNSBACH*}

In this paper I will use concepts from innovation theory to analyse the work of the Court of Justice of the European Union in its important role as sole interpreter of EU law. In that regard, I define 'innovator' as one that facilitates use of new or existing inventions. Thus innovation is portrayed as a process in which several actors may contribute and where it all starts with an invention (the solution) and it ends with the innovation (the process of making use of the invention). The Court of Justice of the European Union may be an inventor in as much as it is allowed to invent solutions in order to solve new or existing problems, and it may be innovative in as much as it hands down judgments that shall be followed (i.e. it makes use of the invention).

The substance of the paper deals with case-law from the Court of Justice of the European Union in the field of cross-border infringements. The cases will be analysed in relation to the idea that legal decision-making can be described as an innovative process. An approach like this makes it possible to draw conclusions regarding the Court of Justice of the European Unions ability to innovate. It will be apparent that the Court is primarily concerned with so called reactive innovation (i.e. innovation that builds on existing knowledge). Only in exceptional circumstances do we find examples where the Court has proved to conduct in proactive innovation (i.e. inventing and applying new solutions) and this may, according to the author, prove to be a preferred standard. Better to drive safely than to drive in the ditch. 


\section{KEY WORDS}

Legal Innovation, Private International Law, Jurisdiction, EU Law, Court of Justice of the European Union (CJEU)

\section{INTRODUCTION}

If law were described as a construction that had the ability to be innovative, as I think it should be, the actors in the legal market - using innovation theory terminology - are important entrepreneurs and a necessary driving force in the innovation process. ${ }^{1}$ Among such actors are the courts, and in the realm of EU law, the most important is the Court of Justice of the European Union (CJEU).

The CJEU, with its monopoly on interpretation of EU law and its capacity to hand down judgments that shall be followed bycourts in Member States may be defined as both a potential inventor and a potential innovator. It may be an inventor in as much as it is allowed to solve problems with new solutions (e.g. invent new solutions to new or existing problems), and it may be innovative in as much as it hands down judgments that are decisive, e.g. there is a guarantee that the new suggested solution will be used by others, which generally is a central prerequisite for innovation. ${ }^{2}$

In this paper, I have no ambition to develop the idea to describe legal decision-making in terms of innovation, but I will use concepts from innovation theory to analyse the work of the CJEU in its important role as sole interpreter of EU law. In that regard, I define "innovator" as one that facilitates use of new or existing inventions. Thus innovation is portrayed as a process in which several actors may contribute and where it all starts with an invention (the solution) it ends with the innovation (the process of making use of the invention).

In relation to innovative legal decision-making, I have previously argued in favour of an approach that accentuates that the better innovator may be the actor that possesses the ability to listen, i.e. pick up inventive solutions

See e.g Schumpeter, J.A. (1934) the Theory of Economic Development. Harvard University Press.; Rosenberg, N. and Birdzell, L.E. (1986) How the West Grew Rich - the Economic Transformation of the Industrial World. Basic Books.; Salzberger, Eli M., (ed.) (2012) Law and Economics of Innovations. Edward Elgar.

2 See Maunsbach, U. (2017) How to Facilitate Legal Innovations - Like Home Cooking with a Twist [Online]. Owen Dixon Society eJournal. Available from: http://epublications.bond.edu.au/ odsej/10 [Accessed 12 June 2017]. 
among the actors in the legal market and make use of them, rather than the actor that possesses the ability to invent. Irrespective of the efficiency aspect - that it is an advantage to benefit from the work already done by others - it is clear that the inventor ought to be separated from the innovator. Although these two quite frequently coincide - the inventor and the innovator might very well be the same actor - it is essential to stress that their skills differ. The inventor needs to be creative and focused (even narrow minded), whereas the innovator, as already stated, needs to listen, be open-minded and be ready to make use of inventive solutions irrespective of their origin.

Henceforth case-law from the CJEU in the field of cross-border infringements will be analysed in relation to the idea that legal decisionmaking can be described as an innovative process. An approach like this not only provides the author with a possibility to go through a number of cases that have already been studied exhaustively, it also (and hopefully more importantly) makes it possible to draw new conclusions in relation to CJEU actions regarding this important institution's ability to innovate. It also allows for some conclusions as to whether or not the CJEU is building on existing knowledge or inventing new solutions, i.e. if innovations from the CJEU are reactive or proactive.

From this starting point, I have decided to take a new look at the increasing case-load that deals with Internet related infringements (of different sorts). The aim in this paper is to shed new light on the on-going development and, if possible, to say something about the innovativeness in relation to how the CJEU is approaching problems related to the Internet. While analysing cases, I will primarily focus on the court's assessment of jurisdiction, i.e. how the court is interpreting different rules in the Brussels Ia regulation, ${ }^{3}$ and not include various aspects that regard the interpretation of rules in other instruments. Particular attention will be paid to the CJEU's argument in relation to how Internet related problems are supposed to be handled, not only including arguments

3 In this paper I will generally refer to Regulation (EU) No. 1215/2012 of the European Parliament and of the Council of 12 December 2012 on jurisdiction and the recognition and enforcement of judgments in civil and commercial matters (Brussels Ia Regulation), although most of the case-law analysed are actually interpreting its predecessor, Council Regulation (EC) No 44/2001 of 22 December 2000 on jurisdiction and the recognition and enforcement of judgments in civil and commercial matters. as regards the issues that are being dealt with in this paper the substantive rules are the same in both Regulations and I have therefore, throughout the paper, consistently taken the liberty of updating cases with references to the corresponding articles of the new regulation. 
it aims at answering but also the questions that are actually dealt with in the case. Put differently, I will try to identify the solutions that are put forward by the CJEU, acknowledging the fact that the analytical framework is decided by the preliminary questions and that some of the reasoning is obiter dictum.

The structure of the paper is straight forward. I will start out with a presentation of the decided cases so far (until December 2016). Cases have been chosen due to their relevance in relation to the fact that they relate to problems as to jurisdiction in Internet related cases. I will cover the cases in chronological order starting with the Pammer $\mathcal{E}$ Alpenhof case of 7 December 2010 and ending with the Concurrence case of 21 December $2016{ }^{4}$

The purpose of the presentation is to pinpoint how the CJEU is addressing Internet related problems present in each case, and throughout the analysis I will keep to the following structure. Starting in Chapter Two, I will first specify the point of law that is relevant in the case. To a large extent, the national courts decide this inasmuch as it is the courts of the Member States that actually formulate the questions that need to be answered. It may, however, be necessary to clarify and/or rewrite the original questions, and it will be necessary to skip questions that aim at issues outside the scope of this paper. Secondly, I want to clarify the rule of law that may be derived from the case. This is, in the best of worlds, something directly provided for in the judgment, and I will primarily, for obvious reasons, derive my rules of law from this source. It may, however, be necessary to analyse the rule of law in light of the reasoning, and it will prove possible to rewrite the judgment into more abstract rules. Finally, I will focus on the mode of procedure, e.g. how the CJEU have actually approached the Internet challenge. It is primarily during this last stage of the presentation that it will be possible to say something about the innovativeness of the CJEU, although this

\footnotetext{
Case covered in this survey are: C-144/09 \& C-585/08 (Pammer and Alpenhof), 7 December 2010 (Grand Chamber), EU:C:2010:740; C-509/09 \& C-161/10 (E-date and Martinez), 25 October 2011 (Grand Chamber), EU:C:2011:685; C-523/10 (Wintersteiger), 19 April 2012 (First Chamber), EU:C:2012:220; C-173/11 (Dataco), 18 October 2012 (Third Chamber), EU:C:2012:642; C-170/12 (Pinckney), 3 October 2013 (Fourth Chamber), EU:C:2013:635; C-387/12 (Hi Hotel), 3 April 2014 (Forth Chamber), EU:C:2014:215; C-360/12 (Coty Germany), 5 June 2014 (Forth Chamber), EU:C:2014:1318; C-441/13 (Hejduk), 22 January 2015 (Forth Chamber), EU:C:2015:28; C-322/14 (El Majdoub) 21 May 2015 (Third Chamber), EU:C:2015:334 and Case C-618/15 (Concurrence) on 21 December 2016 (Third Chamber), EU:C:2016:976.
} 
analysis is primarily saved for the last section of the paper, Chapter Three, during which a concluding analysis will be presented.

\section{AN INNOVATION ANALYSIS OF CJEU CASE-LAW}

\subsection{PAMMER \& ALPENHOF}

\subsubsection{POINT OF LAW}

On 7 December 2009, the Grand Chamber of the CJEU delivered its judgment in the joined Pammer $\mathcal{E}$ Alpenhof case. ${ }^{5}$ In this landmark case, the CJEU had, for the first time, the opportunity to interpret the meaning of "directed activities" in relation to website activities within the frames of Article 17(1)c of the Brussels Ia Regulation. The case dealt with two similar situations. In the Pammer case, it was an Austrian consumer who was arguing for jurisdiction in Austria in relation to a dispute with a trader in Germany that according to the plaintiff (the consumer) had directed online activities to Austria in a way that made Article 17(1)c applicable. In the Alpenhof case, it was the other way around. A trader in Austria initiated proceedings in Austria against a consumer from Germany, who counterclaimed that there was no jurisdiction in Austria due to the fact that the trader had directed online activities towards Germany. By doing so, the same provision was made applicable (Article 17(1)c) with the consequence that the German consumer should benefit from the protecting rule in Article 18, stating that a consumer always can demand that a case against the consumer is to be tried in a court in the country of the consumers domicile. Both cases dealt with activities conducted on the Internet and the core issue was the interpretation of Article 17(1)c in the Brussels Ia Regulation and the prerequisite

"directing commercial or professional activities to the Member State of the consumers domicile".

The point of law of relevance dealt with in this case may consequently be stated in the following way: how is Article $17(1) \mathrm{c}$ in the Brussels Ia Regulation and the expression

"directing commercial or professional activities to the Member state of the consumers domicile"

5 Peter Pammer v. Reederei Karl Schlüter GmbH \& Co KG and Hotel Alpenhof GesmbH v. Oliver Heller (2010) joined cases C-585/08 and C-144/09, Court of Justice of the European Union (Grand Chamber), 7 December. 
to be interpreted in relation to online activities? an alternative way of expressing this would be whether it is sufficient to be online or if some other website activities are necessary in order for a trader's action to be regarded as directed to the Member State of the consumer's domicile in a way that makes the consumer-protection rules in the Brussels Ia Regulation applicable. ${ }^{6}$

\subsubsection{RULE OF LAW}

The rule of law that can be derived from the judgment in the Pammer $\mathcal{E}$ Alpenhof case may be framed as follows: if a trader is offering goods or services for online sales, the prerequisite "directing professional activities" in Article 17(1)c of the Brussels Ia Regulation is not satisfied merely due to the accessibility of the trader's website; but if it is apparent from the trader's, or an intermediary's, overall website activity that the trader was envisaging doing business (i.e. conclude contracts) with consumers in the Member State of the consumer's domicile, the requirements are satisfied.

The closer assessment as regards the prerequisite "directing professional activities" is for the national courts to ascertain, i.e. whether the overall website activity incase is sufficient for it to be regarded as "directed activity". The CJEU provides some additional help in as much as the judgment includes a non-exhaustive list of matters that may be evidence in support of a finding that a trader's activity is directed to the Member State of the consumer's domicile. The list comprises more or less obvious matters, and it highlights the importance of prior international trade, use of language and use of currency. It also places importance on more Internet-related matters like the use of country specific top-level domains and marketing activities by way of Internet referencing services.

\subsubsection{MODE OF PROCEDURE}

In its reasoning the CJEU is more elaborate than in the judgment. In relation to the list of factors that may constitute evidence regarding directed activities, the CJEU differentiates between "patent evidence" and other items

Peter Pammer v. Reederei Karl Schlüter GmbH \& Co KG and Hotel Alpenhof GesmbH v. Oliver Heller (2010) joined cases C-585/08 and C-144/09, Court of Justice of the European Union (Grand Chamber), 7 December. $§ 47$. 
of evidence. Patent evidence would, for example, be if it is mentioned on the trade's website that the trader is offering its goods or services in the consumer's Member Sate or if the trader has had expenditure for marketing activities in the consumer's Member State. Other items of evidence are such that, in combination with each other, may lead to the conclusion that a trader's activities are directed to another Member State. The list in the judgment includes examples from the latter group but not examples of patent evidence. Presumably this is due to the fact that patent evidence is regarded as obviously influential. ${ }^{7}$

The Pammer $\mathcal{E}$ Alpenhof case is a landmark case in as much as it discusses how directed professional activities are to be interpreted for the first time. In its reasoning, the Grand Chamber is attentive to specific Internet-related circumstances, and it acknowledges that the vulnerability of consumers increases due to the development of Internet communication. ${ }^{8}$ Simultaneously, the CJEU shows an understanding as regards the fact that commercial online activities are ubiquitous and consequently globally assessable; it may prove difficult to delimit access to online offers, not least in light of the fact that there are mandatory requirements regarding some information that needs to be provided in the case of services offered online. ${ }^{9}$ as a result, the trader must have manifested its intention to conduct business with the consumer in order to make Article 17(1)c applicable.

The Pammer $\mathcal{E}$ Alpenhof case may be framed as an innovative case, in as much as it shows that the CJEU possesses the ability to be attentive - adopting functional principles - in relation to a new problem, i.e. to what extent Internet related activities can be regarded as directed to a specific Member State. In this regard, this case, and the rule of law that may be derived from it, could be defined as a case that illustrates that the CJEU is reactive in its capacity as innovator. It actually strives to solve a new problem - by addressing the problem of how Internet related activities are supposed to be demarcated - but the solution is not an invention; it is rather

7 Peter Pammer v. Reederei Karl Schlüter GmbH \& Co KG and Hotel Alpenhof GesmbH v. Oliver Heller (2010) joined cases C-585/08 and C-144/09, Court of Justice of the European Union (Grand Chamber), 7 December. § 81-83.

$8 \quad$ Ibid., $\S 62$.

9 Ibid., § 68 and 78, with further reference to Article 5(1)c Directive 2000/31/EC of the European Parliament and of the Council of 8 June 2000 on certain legal aspects of information society services, in particular electronic commerce, in the Internal Market (E-commerce Directive). Official Journal of the European Union (2000/L 178/1) 17 July. Available from: http://data.europa.eu/eli/dir/2000/31/oj [Accessed 12 June 2017]. 
an interpretation based on existing knowledge applied in relation to a new problem.

\subsection{EDATE AND MARTINEZ}

\subsubsection{POINT OF LAW}

Almost one year later, on 25 October 2011, the Grand Chamber had the opportunity to add to the knowledge as regards Internet related activities in its judgment in the joined eDate $\mathcal{E}$ Martinez cases. ${ }^{10}$ Both cases deal with Internet-related defamation where the action - the event that gave rise to damage - was located in one country and potential damages in another. In both cases, the plaintiff sued on basis of the special jurisdictional rule in Article 7(2) of the Brussels Ia Regulation, but not in the country where the tortious action took place and not in the country where the defendants were domiciled. In the $e$ Date case, proceedings were brought before a court in Germany in relation to actions that took place on a website in Austria, and in the Martinez case proceedings were brought before a French court in relation to actions that took place on a website in the UK. In both cases, questions arose as to whether this special rule on international jurisdiction in Article 7(2) was applicable.

In addition to this question, the eDate case also includes a question as to applicable law and how the e-commerce directive is supposed to be interpreted. For the purpose of this paper, however, I will focus on the question regarding jurisdiction.

The point of law - with relevance for this study - in both cases is how the expression "the place where the harmful event occurred or may occur", in Article 7(2) of the Brussels Ia Regulation, is to be interpreted in the case of an alleged infringement of personality rights by means of content placed online on an Internet website.

\subsubsection{RULE OF LAW}

The CJEU provides an answer narrowed down to the specific situation that is relevant for a person in the event of an alleged infringement of personality rights by means of content placed online on an Internet website. In this specific situation, the rule of law is that a person who

10 eDate Advertising GmbH v. X and Olivier Martinez, Robert Martinez v. MGN Limited (2010) joined cases C-509/09 and C-161/10, Court of Justice of the European Union (Grand Chamber), 25 October. 
considers that his/her rights have been infringed may bring an action for liability under Article 7(2) in respect of all the damage caused before the courts of the Member State in which the centre of his/her interest is based.

This ruling, seen in light of prior case-law, means that Article 7(2) provides for three separate jurisdictional heads. The first two are derived from prior case-law. ${ }^{11}$ Firstly, the plaintiff may bring an action before the courts of the Member State in which the publisher of the defamatory content is established. Secondly, the plaintiff may, instead of an action for liability in respect of all the damage caused, bring an action before the courts of each Member State in the territory of which content placed online is or has been accessible. This latter group of courts have jurisdiction only in respect of the damage caused in the territory of the Member State of the court seized. The third option is the inventive addition that is introduced by the eDate $\mathcal{E}$ Martinez case, namely a possibility for the plaintiff to bring an action covering all damage caused before the courts of the Member State in which the centre of the plaintiffs' interests is based.

\subsubsection{MODE OF PROCEDURE}

In this case, the CJEU is indeed both an inventor and innovator. The introduction of a third jurisdictional head based on the plaintiff's centre of interest is a novel solution. It is likely that inspiration is derived from similar solutions in common-law, where "centre of interest theories" are quite common ${ }^{12}$ - but the way the CJEU is tailoring this idea in relation to online infringements of personality rights must be regarded as an invention. The reasoning in this regard is expressly emphasising the ubiquitous nature of the Internet. It initially departs from the Shevill case - in which the second jurisdictional head of Article 7(2) was defined - and it is concluded that the two connecting criteria in the Shevill case would provide the victim with a possibility to bring an action for damages against the publisher either before the courts of the Member State of the place where the publisher of the defamatory publication is established, which

11 See further Handelskwekerij G. J. Bier BV v. Mines de potasse d'Alsace SA (1976) case C-21/76, Court of Justice of the European Union, 30 November. EU:C:1976:166. And Fiona Shevill, Ixora Trading Inc., Chequepoint SARL and Chequepoint International Ltd v. Presse Alliance SA (1995) case C-68/93, Court of Justice of the European Union, 27 March.

12 See e.g. Shapira, A., the Interest Approach to Choice of Law, Martinus Nijhoff, 1970. 
have jurisdiction to award damages for all of the harm caused by the defamation, or before the courts of each Member State in which the publication was distributed and where the victim claims to have suffered injury to his reputation, which have jurisdiction to rule solely in respect of the harm caused in the State of the court seised. ${ }^{13}$

The CJEU then concludes that the Internet reduces the usefulness of the criterion defined in the Shevill case. It may prove difficult to delimit damage to a specific Member State when information is placed online, taking account to the ubiquitous nature of the Internet, and the risk of serious harm. ${ }^{14}$ The CJEU is specifically emphasising

"the serious nature of the harm which may be suffered by the holder of a personality right who establishes that information injurious to that right is available on a world-wide basis."

It is in reaction to these considerations that the CJEU decides that it is necessary to invent a new jurisdictional head within the frames of Article 7(2).

Consequently, the $e$ Date $\mathcal{E}$ Martinez case includes an inventive aspect that makes this case an example where the CJEU may be said to adhere to proactive innovation rather than reactive.

\subsection{WINTERSTEIGER}

\subsubsection{POINT OF LAW}

After the two landmark cases in 2010 and 2011, responsibility for the further development of case-law was handed over to the separate chambers of the CJEU. Consequently, on 19 April 2012, the First Chamber delivered its judgment in the case of Wintersteiger. ${ }^{15}$ The dispute regards use of the Austrian, nationally registered, trademark "Wintersteiger". The Austrian proprietor of that trademark brought an action before an Austrian court, claiming that the defendant, a company residing

13 eDate Advertising GmbH v.X and Olivier Martinez, Robert Martinez v. MGN Limited (2010) joined cases C-509/09 and C-161/10, Court of Justice of the European Union (Grand Chamber), 25 October. \& 42, with further reference to Fiona Shevill, Ixora Trading Inc., Chequepoint SARL and Chequepoint International Ltd v. Presse Alliance SA (1995) case C-68/93, Court of Justice of the European Union, 27 March. §33.

14 eDate Advertising GmbH v.X and Olivier Martinez, Robert Martinez v. MGN Limited (2010) joined cases C-509/09 and C-161/10, Court of Justice of the European Union (Grand Chamber), 25 October. $\S 45-47$.

15 Wintersteiger AG v. Products $4 U$ Sondermaschinenbau GmbH. (2012) case C-523/10, Court of Justice of the European Union (First Chamber), 19 April. 
in Germany, had infringed the Wintersteiger trademark by use of keyword advertising placed on the google.de website and that the use in question made Article 7(2) of the Brussels Ia Regulation applicable. The defendant contested jurisdiction arguing that advertisement on a website registered under a national top-level domain is directed to users in that country only.

Hence the question that eventually came before the CJEU regards what criteria are to be used to determine jurisdiction under Article 7(2) of Brussels Ia Regulation to hear an action relating to an alleged infringement of a nationally registered trademark through the use of a keyword identical to that trademark on the website of an Internet search engine operating under a top-level domain different from that of the Member State where the trademark is registered. ${ }^{16}$

\subsubsection{RULE OF LAW}

In relation to this question the rule of law that may be derived from the judgment of the CJEU may be framed as follows: when an actor places keyword advertising on a website identical to a trademark registered in a Member State, the top-level domain under which the website is registered has no influence on the question as to jurisdiction under Article 7(2) of Brussels Ia Regulation. Thus, an action relating to infringement in such a case may be brought before either the courts of the Member State in which the trademark is registered or the courts of the Member State of the place of establishment of the advertiser.

Put differently the CJEU acknowledges the first two jurisdictional heads of Article 7(2), but it disregards the third possibility that was provided by the eDate $\mathcal{E}$ Martinez case.

\subsubsection{MODE OF PROCEDURE}

In its reasoning the CJEU develops rather extensively why the circumstances in the case differ from those in the eDate $\mathcal{E}$ Martinez case, and it concludes that infringements of personality rights differ in important aspects from nationally registered trademarks. Personality rights are protected in all Member States, whereas nationally registered trademarks are protected in one country only and a proprietor of such a right cannot rely on protection outside the territory of the protecting country. ${ }^{17}$ It is thus

16 Ibid., $\$ 17$.

17 Ibid., § 22-25. 
logical, according to the CJEU, that the protecting country is the only place where damage in relation to infringement of a national trademark can take place and, therefore, courts in that country are best able to assess the infringement claim. Consequently the second jurisdictional head, based on damage, of Article $7(2)$ is applicable in the case and, in contrast to the situation in the Shevill case - taking account to the fact that a national trademark is limited to the territory of the protecting country - a court under that jurisdiction, as a matter of fact, will be competent to try all the damages that occur whereas there is no possibility that a nationally registered trademark can be harmed outside of the protecting country.

In relation to the first jurisdictional head of Article $7(2)$, based on the action - i.e. the event giving rise the damage - the CJEU focus on the activities performed by the advertiser. It is, according to the CJEU,

"the activation by the advertiser of the technical process displaying, according to pre-defined parameters, the advertisement which it created for its own commercial communications which should be considered to be the event giving rise to an alleged infringement, and not the display of the advertisement itself."18

In support of this finding, the CJEU refers both to prior case-law and the objective of foreseeability arguing that

"the place of establishment of that server cannot, by reason of its uncertain location, be considered to be the place where the event giving rise to the damage occurred [...]."19

The finding in the Wintersteiger case is rather reactive than proactive, and it is a case that fully supports the idea that intellectual property rights are territorial and hence best adjudicated in the country of protection.

18 Wintersteiger AG v. Products 4U Sondermaschinenbau GmbH. (2012) case C-523/10, Court of Justice of the European Union (First Chamber), 19 April. § 34.

19 Ibid., § 35-36. See also Google France SARL and Google Inc. v. Louis Vuitton Malletier SA; Google France SARL v. Viaticum SA and Luteciel SARL and Google France SARL v. Centre national de recherche en relations humaines (CNRRH) SARL and Others (2010) joined cases C-236/08, C-237/08 and C-238/08, Court of Justice of the European Union, (Grand Chamber), 23 March 2010. 


\subsection{DATACO}

\subsubsection{POINT OF LAW}

The next relevant case to mention, after the Wintersteiger case, is the Third Chamber's judgment in the Dataco case. ${ }^{20}$ The judgment was delivered on 18 October 2012, and it is worth mentioning in relation to the Brussels 1a Regulation, although this case primarily concerns applicable law. The dispute regards certain rights in relation to a database containing data collected from on-going football matches. The proprietor of this database, a UK-based company Football Dataco, claimed that the Swiss/German Company Sportsradar had infringed Football Dataco's rights and brought infringement actions before a UK court. In relation to the dispute at hand, there was two questions: one that related to the interpretation of the database directive and the concept of extraction and re-utilisation and one general question regaring where such an act takes place. In the following, I will concentrate my analysis on this latter question.

Thus the question that will be dealt with regards cross-border use of proprietary data and where such use takes place in situation where the information is stored on server in one country and made available in another. This question relates in general terms to the wider issue how Internet-related acts are to be delimited and in that regard the problem is similar to the discussion about "directed professional activities" in the Pammer $\mathcal{E}$ Alpenhof case.

The point of law that is relevant in this part of the judgment can be phrased as follows: in a situation when someone located in one Member State extracts information stored on a server in another Member State, is the act of extraction taking place in the Member State where the server is located, in the Member State where the information is made available, or in both those States? ${ }^{21}$

\subsubsection{RULE OF LAW}

In relation to this question, the CJEU delivers a rather open-ended and inventive rule of law. It states that the act of extraction takes place, at least, in the Member State where the information is made available, where there is evidence from which it may be concluded that the act

20 Football Dataco Ltd and Others v. Sportradar GmbH and Sportradar AG (2012) case C-173/11, Court of Justice of the European Union (Third Chamber), 18 October.

$21 \quad$ Ibid., $§ 18$ 
discloses an intention on the part of the person performing the act to target members of the public in that Member State. This rule of law is inventive in as much as it introduces "intention" as a pre-requisite for the localisation of use in a specific territory and it is open-ended in as much as it does not specify the closer meaning what "intention to target" may be, although some guidance is provide for in the reasoning.

The CJEU refers to the Pammer $\mathcal{E}$ Alpenhof case and suggest a similar list of criteria that may indicate intention, namely that there is evidence that business is conducted with users in the territory and whether country specific language is used. However, the examples are, in contrast to the list in the Pammer $\mathcal{E}$ Alpenhof case, not included in the judgment but provided in the reasoning obiter dicta. ${ }^{22}$ It is also worth noticing that this judgment primarily deals with the issue whether UK database protection is applicable and not to what extent UK-courts have jurisdiction to hear the case, although the CJEU acknowledges that the question of localisation of a tortious act is liable to have an influence also on the question of jurisdiction. ${ }^{23}$

\subsubsection{MODE OF PROCEDURE}

The reasoning in the Dataco case follows rather closely the reasoning in the Pammer $\mathcal{E}$ Alpenhof case and the findings from this case is applied to a situation in which there are no objective to protect weak party interest. Specific account is taken of the ubiquitous nature of a website, and it is confirmed that the mere fact that a website is accessible in a particular national territory is not a sufficient basis for the localisation of an tortious act in that territory in relation to questions as regards applicable national law. If the mere fact of being accessible were sufficient, the CJEU concludes that there is a risk that certain conducts would wrongly be subject to the application of national laws that should not apply. ${ }^{24}$

Overall the reasoning in the Dataco case is attentive to Internet-related problems, and in this regard the judgment may be defined as proactive rather than reactive.

\footnotetext{
22 Football Dataco Ltd and Others v. Sportradar GmbH and Sportradar AG (2012) case C-173/11, Court of Justice of the European Union (Third Chamber), 18 October. § 41-42.

23 Ibid., $\$ 30$.

${ }^{24}$ Ibid., § 35-38.
} 


\subsection{PINCKNEY, HI HOTEL, COTY GERMANY AND HEJDUK}

\subsubsection{POINTS OF LAW}

Following the Third Chamber's decision in the Dataco case, the Forth Chamber delivered a series of judgments regarding the closer meaning of Article 7(2) of the Brussels Ia Regulation in relation to different sorts of infringements: the Pinckney case on 3 October $2013,{ }^{25}$ the Hi Hotel case on 3 April 2014, ${ }^{26}$ the Coty Germany case on 5 June $2014^{27}$ and the Hejduk case on 22 January $2015 .^{28}$

In these cases, there are a similar questions as regards international jurisdiction when the infringement claim is brought before courts in other Member States than the ones in which the tortious act took place.

In the Pinckney case, a composer (and proprietor of copyright) brought an infringement action before a French court against an Austrian actor who had reproduced CDs that had been marketed and sold online by UK companies. During the proceeding, the defendant contested that there was international jurisdiction in France; the question arose as to whether Article 7(2) of the Brussels Ia Regulation must be interpreted as meaning that where there is an alleged infringement of a copyright which is protected by the Member State of the court seised, that court has jurisdiction to hear an action to establish liability brought by the author of a work against a company established in another Member State, which has reproduced that work on a material support which is subsequently marketed by companies established in a third Member State through an Internet site which is also accessible in the Member State of the court seised. ${ }^{29}$

In the Hi Hotel case, different claims regarding copyright infringement were brought before a court in Germany (Cologne) by a photographer who had transferred rights to a number of photos of various rooms in a French hotel (Hi Hotel in Nice) under a transfer agreement that limited the use of the photos to Hi Hotel only. The photos later appeared in a book,

${ }^{25}$ Peter Pinckney v. KDG Mediatech AG (2013) case C-170/12, Court of Justice of the European Union (Forth Chamber), 3 October.

${ }^{26}$ Hi Hotel HCF SARL v. Uwe Spoering (2014) case C-387/12, Court of Justice of the European Union (Forth Chamber), 3 April.

27 Coty Germany GmbH v. First Note Perfumes NV (2014) case C-360/12, Court of Justice of the European Union (Forth Chamber), 5 June.

${ }^{28}$ Pez Hejduk v. EnergieAgentur.NRW GmbH (2015) case C-441/13, Court of Justice of the European Union (Forth Chamber), 22 January.

29 Peter Pinckney v. KDG Mediatech AG (2013) case C-170/12, Court of Justice of the European Union (Forth Chamber), 3 October. $\S 22$. 
published by a German publisher, that was available in abookshop in Cologne and consequently proceedings were brought there. The defendant contested jurisdiction and argued that it possibly had made the photos available to the publisher's subsidiary in Paris and that it potentially was the subsidiary that passed them on to its German sister company. From the case it is apparent that there are several supposed perpetrators of the damage allegedly caused. On the basis of these conditions the point of law in relation to the proceedings is if Article 7(2) of the Brussels Ia Regulation should be interpreted as meaning that jurisdiction may be established with respect to one of those perpetrators who did not act within the jurisdiction of the court seised. ${ }^{30}$

In the Coty Germany case, proceedings were brought before a German court against a Belgian wholesaler who had sold perfumes through an intermediary in Germany that was claimed to infringe trademark rights in Germany. Due to the fact that the trademark in question was an EU trademark, protected under the EU trademark Regulation (which also regulates the competence of EU trademark courts) ${ }^{31}$, the question that became relevant in relation to international jurisdiction in Germany regarded separate claims based on national German laws regarding unfair competition. Such claims are not covered by the EU trademark regulation, and consequently there is nothing in the EU trademark Regulation that prevents those claims from being brought before a court that is competent under the Brussels Ia Regulation. The point of law that will be further discussed is whether Article 7(2) must be interpreted as meaning that, in the event of an allegation of unlawful comparative advertising or unfair imitation of a sign protected by a EU trademark, prohibited by the law against unfair competition of the Member State in which the court seised is situated, that provision attributes jurisdiction to hear an action for damages based on that national law against one of the presumed perpetrators who is established in another Member State and is alleged to have committed the infringement in that State. ${ }^{32}$

30 Hi Hotel HCF SARL v. Uwe Spoering (2014) case C-387/12, Court of Justice of the European Union (Forth Chamber), 3 April. $\S 23$.

31 See further Council Regulation (EC) No. 207/2009 of 26 February 2009 on the Community trademark (codified version) (EU-trademark Regulation). Official Journal of the European Union (2009/L 78/1) 24 March. Available from: http://data.europa.eu/eli/reg/2009/207/oj [Accessed 12 June 2017].

32 Coty Germany GmbH v. First Note Perfumes NV (2014) case C-360/12, Court of Justice of the European Union (Forth Chamber), 5 June. § 39. 
And finally, in the Hejduk case, claims regarding copyright infringement were brought before an Austrian court against a German defendant who had published photos on a German website supposedly not directed at Austria. The point of law was whether Article 7(2) must be interpreted as meaning that, in the event of an allegation of infringement of rights related to copyright which are guaranteed by the Member State of the court seised, that court has jurisdiction to hear an action for damages in respect of an infringement of those rights resulting from the placing of protected photographs online on a website accessible in its territorial jurisdiction. ${ }^{33}$

Simply put, the point of law in these four cases regards how acts that constitute distance delict, e.g. tortious act that takes place in one jurisdiction and that have effect in another, are to be handled within the frames of Article 7(2) of the Brussels Ia Regulation; it is therefore appropriate to summarise the findings in one general rule of law.

\subsubsection{RULES OF LAW}

Read together, the rule of law that may be derived from these four cases may be framed as follows: Article 7(2) provides for international jurisdiction based on the fact that damage occurred in the Member State of the court seised, and that court will be competent as regards damage that occurs in that country following an infringement conducted by a defendant domiciled in another Member State who has made copyright or trademark protected works assessable from the state of the court seised, irrespective of the fact that the defendant did not act in that state. In this regard, it is irrelevant if the defendant acted through intermediaries in other Member States. If jurisdiction is based on the occurrences of damages, the only prerequisite that is relevant is whether or not damage may occur in the Member Sate of the court seised, and regarding online infringement, it is sufficient for international jurisdiction under Article 7(2) if protected works has been made accessible in the country of the court.

\subsubsection{MODE OF PROCEDURE}

In their reasoning, the Fourth Chamber relates to the Shevill case in its assessment of jurisdiction under Article 7(2). The third jurisdictional head that was introduced in the eDate $\mathcal{E}$ Martinez case is not applicable,

${ }^{33}$ Pez Hejduk v. EnergieAgentur.NRW GmbH (2015) case C-441/13, Court of Justice of the European Union (Forth Chamber), 22 January. § 15. 
nor is the discussion regarding intention to target from the Dataco case. Instead the Fourth Chamber confirms the idea that infringement claims based on national rights are best adjudicated in a court where the damage occurred ( in a court where the act took place - which in the four cases coincides with the courts of the defendant's domicile).

In this regard, the judgments from the Fourth Chamber are obvious examples of reactive innovation where the CJEU is applying existing knowledge to further develop that understanding of Article 7(2).

\subsection{EL MAJDOUB}

\subsubsection{POINT OF LAW}

The next Internet-related case of relevance is the El Majdoub case, which was delivered by the Third Chamber on 21 May 2015. ${ }^{34}$ The dispute regarded an agreement to purchase an electric car which, after the conclusion of the sales contract, was cancelled. The parties to the dispute had dissenting opinions as regarded the reasons for the cancellation, and the purchaser (a car dealer established in Cologne) brought action before a court in Krefeld (Germany) regarding the transfer of ownership of the vehicle in question. In that situation, the defendant (the seller) claimed that there was no jurisdiction. The principal argument in support of that claim was that a prorogation clause conferring jurisdiction on a court in Leuven (Belgium) was included in the general terms and conditions for Internet sales transactions and that this clause was applicable in the case due to the fact that the purchase was made from the sellers website, from which the terms and conditions was presented by way of a pop-up window that appeared and had to be clicked on in order to complete the purchase (i.e. click wrap agreement).

The question arose whether or not the terms and conditions (including the prorogation clause) had been validly incorporated into the sale agreement. In Article 25(2) of the Brussels Ia Regulation, it is made clear that a written prorogation clause provides for jurisdiction and that

"any communication by electronic means which provides a durable record of the agreement shall be equivalent to writing."

\footnotetext{
34 Jaouad El Majdoub v. CarsOnTheWeb.Deutschland GmbH (2015) case C-322/14, Court of Justice of the European Union (Third Chamber), 21 May.
} 
Thus, the point of law that became relevant in the El Majdoub case was whether Article 25(2) of the Brussels Ia Regulation must be interpreted as meaning that the method of accepting general terms and conditions of contract for sale by "click-wrapping", concluded electronically, containing an agreement conferring jurisdiction, constitutes a communication by electronic means capable of providing a durable record of that agreement within the meaning of that provision. ${ }^{35}$

\subsubsection{RULE OF LAW}

As a response to the question raised, the CJEU gave a rather straight forward answer. The rule of law derive from the case is that Article 25(2) must be interpreted as meaning that the method of accepting the general terms and conditions of a contract for sale by "click-wrapping", concluded by electronic means, which contains an agreement conferring jurisdiction, constitutes a communication by electronic means which provides a durable record of the agreement within the meaning of that provision, where that method makes it possible to print and save the text of those terms and conditions before the conclusion of the contract. ${ }^{36}$

\subsubsection{MODE OF PROCEDURE}

The El Majdoub case concerns a novel question, and in that regard the case is a landmark case addressing a new Internet-related question for the first time. This may explain why the CJEU is rather developed in its reasoning. It starts out with a clear reference to the old Brussels Convention ${ }^{37}$ and the fact that Article 25(2) was included in the first Brussels Regulation for a reason [at the time the rule was placed in Article 23(2)], namely to take account to the development of new methods of communication. ${ }^{38}$ It then places importance on the wording and uses a literal interpretation to reach the conclusion that Article 25(2) is about providing a possibility, not a requirement that there should be a physical record of the agreement. ${ }^{39}$

\footnotetext{
Ibid., $§ 20$.

Ibid., $\S 40$.

371968 Brussels Convention on jurisdiction and the enforcement of judgments in civil and commercial matters (Consolidated version), Official Journal of the European Union (1998/C 27/1) 26 January. Available from: http://eur-lex.europa.eu/legal-content/EN/TXT/? uri=OJ:C:1998:027:TOC [Accessed 12 June 2017].

38 Jaouad El Majdoub v. CarsOnTheWeb.Deutschland GmbH (2015) case C-322/14, Court of Justice of the European Union (Third Chamber), 21 May. $\S 32$.

39 Ibid., § 33-34.
} 
In this regard, Article 25(2) differs from seemingly similar provisions regarding protection of consumers in respect of distance contracts, e.g. Article 5(1) of Directive 97/7/EC, ${ }^{40}$ which expressively states that the consumer must receive written confirmation. ${ }^{41}$ Due to the fact that there is no expressed consumer protection objective in relation to the application of Article 25(2), case-law regarding the application of directive 97/7/EC is not relevant in relation to the understanding of Article 25(2) of the Brussels Ia Regulation. ${ }^{42}$

In reaching the conclusion that there should be no requirement that there are written records of a potential agreement on jurisdiction, only a possibility to record a durable evidence of that agreement, I would describe the reasoning and the rule of law in this case as reactive even though it deals with a novel issue. It should be acknowledged that the CJEU establishes a new standard for click-wrap agreements, but they do not invent the idea that a click-wrap solution could amount to a binding agreement; they rather reason in relation to existing knowledge and apply that knowledge in relation to a new problem, hence an example of reactive rather than proactive innovation.

\subsection{CONCURRENCE}

\subsubsection{POINT OF LAW}

The final case that will be covered in this paper is the Third Chamber's judgment on 21 December 2016 in the Concurrence case. ${ }^{43}$ In this case a French retailer, Concurrence, brought action against Samsung as regarded a selective distribution agreement that prevented Concurrence from selling Samsung products through its website. Concurrence questioned the legality of this part of the agreement, with reference to the fact that several other retailers where allowed to conduct online sales. In the dispute before the French court, Concurrence brought actions in relation to both Samsung, regarding the selective distribution agreement, and against several branches

\footnotetext{
40 Directive 97/7/EC of the European Parliament and of the Council of 20 May 1997 on the protection of consumers in respect of distance contracts. Official Journal of the European Union (1997/L 144/19) 4 June. Available from: http://data.europa.eu/eli/dir/ 1997/7/oj [Accessed 12 June 2017].

41 Jaouad El Majdoub v. CarsOnTheWeb.Deutschland GmbH (2015) case C-322/14, Court of Justice of the European Union (Third Chamber), 21 May. § 37-38.

42 Ibid., $\S 38$.

43 Concurrence Sàrl v. Samsung Electronics France SAS and Amazon Services Europe Sàrl (2016) case C-618/15, Court of Justice of the European Union (Third Chamber), 21 December.
} 
of Amazon with the view to obtain an order requiring the withdrawal of any offers for sale of Samsung products directed to the French market that affected Concurrence position as distributor of those products. The lower instances dismissed the claims against Amazon due to lack of jurisdiction and the case was appealed to the Court of Cassation which decided to stay proceedings and forward a preliminarily question to the CJEU.

The point of law relevant in the case may be framed as follows: how shall Article 7(2) of Brussels Ia Regulation be interpreted for the purpose of conferring the jurisdiction given by that provision to hear an action to establish liability for infringement of the prohibition on resale outside a selective distribution network resulting from offers, on websites operated in various Member States, of products covered by that network. ${ }^{44}$

\subsubsection{RULE OF LAW}

In response to the questions asked, the Third Chamber provides a judgment that comprises a rule of law that states that Article 7(2) of Brussels Ia Regulation must be interpreted, for the purpose of conferring the jurisdiction given by that provision to hear an action to establish liability for infringement of the prohibition on resale outside a selective distribution network resulting from offers, on websites operated in various Member States, of products covered by that network, as meaning that the place where the damage occurred is to be regarded as the territory of the Member State which protects the prohibition on resale by means of the action at issue, a territory on which the appellant alleges to have suffered a reduction in its sales. ${ }^{45}$

\subsubsection{MODE OF PROCEDURE}

This case is closely linked to the line of case-law already derived from the CJEU, and it supports the idea that courts in countries in which tortious effect occurs will always be component to try claims regarding that effect. It has been emphasised in relation to infringements of intellectual property rights, in relation to unfair marketing activities and now in relation to loss in sales as regards claims based on arguments related to acts of unfair competition and selective distribution arrangements. In this

$44 \quad$ Ibid., $\S 24$.

45 Ibid., $\S 35$. 
regard, this is a case that confirms the strict application of Article 7(2) in as much as it places importance on the difference between the place where action was committed and the place where damaged occurs; courts in this latter place are best equipped to assess claims in relation to the damage that occurred in that country. Hence, the Third Chamber in this case proves to adhere to reactive innovation.

\section{CONCLUSIONS}

After having assessed the Internet related cases chosen for this paper, with the ambition to penetrate the findings in light of innovation theory, it is now time to draw some tentative conclusions.

One observation would be that the CJEU is reactive rather than proactive. Among the cases dealt with in this paper only two can be defined as proactive, the eDate $\mathcal{E}$ Martinez case from the Grand Chamber and the Dataco case from the Third Chamber, in as much as the CJEU in those two cases actually invented new solutions. Interestingly enough it is apparent that these inventive solutions has not yet been confirmed and applied in later case-law. In contrast to this, it may be stated that reactive cases are more frequently followed. This may be explained by the obvious reason that it is more appropriate to deliver a judgment that is in line with prior case-law than it is to start from a blank sheet and invent a new solution. It may also be stated that there are reasons to be cautious in relation to inventiveness, due to the fact that inventive solutions are less likely to be accepted as a logical continuation of the legal development.

Another reflection in relation to the proactive solution that was chosen in the Dataco case is that this case actually deals with choice of law rather than jurisdiction. In this regard, it can be concluded that there are more profound reasons to be cautious as to the interpretation of rules regarding jurisdiction, due to the fact that it is inappropriate to investigate substantive issues at the jurisdictional stage of the proceedings, which may be required if the circumstances of the case are to be assessed in a proactive way. The fact that the issue in the Dataco case related to the application of national (substantive) law may be the primary reason that explains why the Third Chamber dared to invent a new solution.

As regards the organisation of the CJEU in different chambers, it can furthermore be concluded, perhaps not surprisingly, that inventiveness and proactive innovation primarily seems to reside in the Grand Chamber 
and that the separate chambers, with the exception of the Third Chamber, adhere to reactive innovation in as much as they are more literal in their approach to the problems at hand and more faithful to prior case-law.

From this analysis a cautious conclusion may be drawn in relation to a plaintiff that is about to bring proceedings before a court. It matters how the claims are framed. If the plaintiff wants to plead for new inventions, it may prove problematic if the preliminary question regards jurisdiction, and if that is the case, the remaining hope for an inventive solution is that the CJEU decides to answer the question at hand with a judgment from the Grand Chamber. if the ambition is to urge for inventiveness, which by no reason must be a preferred choice, there seems to be better odds to get a proactive judgment if the preliminary questions deals with substantive law. In this regard, it may be stated that the parties to a dispute, irrespective of the fact that it is the national courts that formulate preliminary questions, have an influence over the proceedings by the way they actually formulates their claims.

A final conclusion, in line with the theme of this paper, would be that the analysis confirms that the CJEU is predominantly reactive in its approach to innovation. When it has challenged the conventions and adhered to proactive innovation - it has seemingly delivered less influential judgments. This conclusion supports the idea that courts shall primarily be reactive and listening - and that there is a danger if courts adhere to untamed inventiveness. Better to listen to the development and adhere closely to a logical line of cases bearing in mind that it is sensitive to speed up the legal development. In this regard, legal developments, according to the CJEU, resemble a slogan that would be fit for a Volvo: drive safe.

\section{LIST OF REFERENCES}

[1] Concurrence Sàrl v.Samsung Electronics France SAS and Amazon Services Europe Sàrl (2016) case C-618/15, Court of Justice of the European Union (Third Chamber), 21 December.

[2] Coty Germany GmbH v. First Note Perfumes NV (2014) case C-360/12, Court of Justice of the European Union (Forth Chamber), 5 June. 
[3] eDate Advertising GmbH v.X and Olivier Martinez, Robert Martinez v MGN Limited (2010) joined cases C-509/09 and C-161/10, Court of Justice of the European Union (Grand Chamber), 25 October.

[4] Fiona Shevill, Ixora Trading Inc., Chequepoint SARL and Chequepoint International Ltd v. Presse Alliance SA (1995) case C-68/93, Court of Justice of the European Union, 27 March.

[5] Football Dataco Ltd and Others v. Sportradar GmbH and Sportradar AG (2012) case C-173/11, Court of Justice of the European Union (Third Chamber), 18 October.

[6] Google France SARL and Google Inc. v. Louis Vuitton Malletier SA; Google France SARL v. Viaticum SA and Luteciel SARL and Google France SARL v. Centre national de recherche en relations humaines (CNRRH) SARL and Others (2010) joined cases C-236/08, C-237/08 and C-238/08, Court of Justice of the European Union, (Grand Chamber), 23 March 2010.

[7] Handelskwekerij G. J. Bier BV v. Mines de potasse d'Alsace SA (1976) case C-21/76, Court of Justice of the European Union, 30 November.

[8] Hi Hotel HCF SARL v. Uwe Spoering (2014) case C-387/12, Court of Justice of the European Union (Forth Chamber), 3 April.

[9] Jaouad El Majdoub v. CarsOnTheWeb.Deutschland GmbH (2015) case C-322/14, Court of Justice of the European Union (Third Chamber), 21 May.

[10] Maunsbach, U. (2017) How to Facilitate Legal Innovations - Like Home Cooking with a Twist [Online]. Owen Dixon Society eJournal. Available from: http://epublications. bond.edu.au/odsej/10 [Accessed 12 June 2017].

[11] Peter Pammer v. Reederei Karl Schlüter GmbH \& Co KG and Hotel Alpenhof GesmbH v. Oliver Heller (2010) joined cases C-585/08 and C-144/09, Court of Justice of the European Union (Grand Chamber), 7 December.

[12] Peter Pinckney v. KDG Mediatech AG (2013) case C-170/12, Court of Justice of the European Union (Fourth Chamber), 3 October.

[13] Pez Hejduk v. EnergieAgentur.NRW GmbH (2015) case C-441/13, Court of Justice of the European Union (Fourth Chamber), 22 January.

[14] Rosenberg, N. and Birdzell, L.E. (1986) How the West Grew Rich - the Economic Transformation of the Industrial World. Basic Books.

[15] Salzberger, Eli M., (ed.) (2012) Law and Economics of Innovations. Edward Elgar.

[16] Shapira, A. (1970) The Interest Approach to Choice of Law. Martinus Nijhoff.

[17] Schumpeter, J.A. (1934) The Theory of Economic Development. Harvard University Press. 
[18] Wintersteiger AG v. Products 4 U Sondermaschinenbau GmbH. (2012) Case C-523/10, Court of Justice of the European Union (First Chamber), 19 April. 